\title{
Effectuating the Settlor's Intent: A Formula for Providing More Income for the Life Beneficiary
}

Trustees, in allocating returns from stock held in trust, ${ }_{1}^{1}$ are controlled by the settlor's intent. Although the settlor may insert specific allocation rules in the trust instrument, he typically expresses his intent by providing simply that "income" be given to a life tenant and that "principal" be preserved for remaindermen. In this situation, the trustee must refer to general trust law to determine how particular receipts are to be treated. In most states, the system of allocating between "principal" and "income" conforms to the Massachusetts rule of allocation adopted by the Uniform and Revised Uniform Principal and Income Acts. ${ }^{2}$ This comment attempts to design a formula for allocating returns from common stocks with an established market price $^{3}$ which is easier to administer and which will more accurately reflect the settlor's probable intent than the Massachusetts rule. Although it is suggested that this formula be adopted by statute or judicial decision as a rule of construction for trust instruments, the formula could be incorporated into such instruments by trust attorneys who find that it would allocate receipts more in accordance with their settlor's intent than would the rule of construction prevailing in their jurisdiction.

Since any rule of allocation must seek to implement the "intent" of the settlor, ${ }^{4}$ an attempt to evaluate allocation methods must investi-

1 Common stocks comprised an estimated $64 \%$ of the $\$ 105,500,000$ in assets held by all commercial banks during 1964 for trust accounts. Silverberg, Bank Trust Investments in 1964, 2 National Banking Rev. 483 (1965).

2 As of December 1965, twenty-seven states had adopted either the Uniform or Revised Uniform Principal and Income Acts (hereinafter cited as UPI and RPI). 3 P-H WiLIs, Estates AND TRusts Serv., If $3945-46$ (1965). Many other states have adopted the Massachusetts rule judicially or legislatively. See, e.g., Powell v. Madison Safe Deposit \& Trust Co., 208 Ind. 432, 196 N.E. 324 (1935); In re Joy's Estate, 247 Mich. 418, 225 N.W. 878 (1929); Hayes v. St. Louis Union Trust Co., 317 Mo. 1028, 298 S.W. 91 (1927); 3 P-H WILLs, Estates AND Trusts SERv., If 5241 (1965); 3 Scotr, Trusts § 236.3 (2d ed. 1956, Supp. 1965) (hereinafter cited as ScoTr).

3 See note 41 infra.

4 Commissioner's Prefatory Note, RPI, 9B UNIForm LAws ANN. (Supp. 1965) ("[T]he settlor's intent is the guiding principle which should control the disposition of all receipts."). See In re Sherman Trust, 190 Iowa 1385, 179 N.W. 109 (1920); Laurent v. Randolph, 306 Ky. 134, 206 S.W.2d 480 (1947); Restatement (SECOND), TRusts \$§ 4, 164; 2 ScotT $\$ \S 164.1,236.4$. But see D’Ooge v. Leeds, 176 Mass. 558, 57 N.E. 1025 (1900).

When the settlor leaves particular common stock in the corpus or includes common stock 
gate what the typical settlor does intend or, more realistically, what he would have intended had he closely considered the matter. ${ }^{5}$ Clearly, the settlor's general purpose in directing that principal be preserved is to insure a continuing source of income for the life tenant with a gift over to the remainderman. If this were his only intent, any allocation rule which did not, by depleting principal, impair the ability of the trust to continue paying income would be acceptable. Of course, princi$\mathrm{pal}$ values will fluctuate with the stock market, but the purchasing power of principal ought not to be depleted over the long run. However, most settlors are primarily interested in the welfare of the life tenant, a bias acknowledged by courts and trust officers. ${ }^{6}$ Therefore, a long-term increase in the constant dollar value of principal should also be avoided, since such an increase would mean that more income could have been paid to the favored life interest without impairing the source of income. An allocation rule should ideally pay out as much income as is consistent with maintenance of the purchasing power of principal. ${ }^{7}$

In addition, simplicity is desirable in an allocation rule because complexity invites litigation and renders administration more difficult. Also, while investment in stocks renders fluctuation of income payments inevitable, the settlor probably desires that this be minimized since fluctuation is bound to upset the life tenant's living patterns. Finally, conflict should be minimized between the rule of allocation and the rules directing trustees to invest as would a prudent man. ${ }^{8}$

The stock allocation rule initiated by the Pennsylvania Supreme

and other assets such as real estate, it may be argued that his selection of assets reflects an intent to provide the life beneficiary only the income actually received from the selected assets. But whether the settlor's actual intent can be inferred from his selection is an issue outside the scope of this comment; the allocation rule suggested here is a rule of construction, and would apply only where the court finds that the settlor's intent cannot be determined from the trust instrument itself.

5 See 3 Scort \& 236.3. Subsequent references to "settlor's intent" and "probable intent" should be taken to include what the settlor probably would have intended had he considered the matter.

6 Ramage v. Ramage, 258 Ala. 81, 61 So. 2d 432 (1952); Title Guarantee Loan \& Trust Co. v. Woodward, 238 Ala. 304, 191 So. 363 (1939); Rosencrans v. Fry, 12 N.J. 88, 95 A.2d 905 (1953); In re Marshall, 43 Misc. 238, 88 N.Y. Supp. 550 (Surr. Ct. 1904); In re Trust Estate of Pew, 411 Pa. 96, 191 A.2d 399 (1963); In re Nirdlinger's Estate, 331 Pa. 135, 200 Atl. 656 (1938) ("[T] Carpenter, The "Fixed-Income," "Annuity" and "Modernized" Types of Trust, 5 LAw \&: Contemp. Prob. 368, 369 (1938); Headly, $A$ Trustee in a World of Changing Values, 5 LAw \& Contemp. Prob. 355, 364 (1938). See 3 ScotT $\$ 236.4$; Bogert, $A$ Project for Improvement of Trust Law, 7 U. CHr. L. REv. 112, 120 (1939).

7 Constant dollars is the significant measure, since inflation can reduce income and principal as effectively as can a decline in the number of dollars.

8 See text accompanying notes 28-31 infra. 
Court in $1857^{\circ}$ was, until the $1930^{\prime}$ 's, preferred by most states. ${ }^{10}$ The Pennsylvania rule allocates regular cash dividends to income. ${ }^{11}$ In addition, whenever an "apportionable event" such as the sale of stock occurs, ${ }^{12}$ the trustee determines what portion of the stock holding's increased value is attributable to retained earnings and allocates this amount to the life tenant. ${ }^{13}$ The Pennsylvania rule's apportionment requirement reflects the view that a corporation's decision to reinvest earnings, made without regard to its effect on trusts, should not be allowed to reduce materially the life tenant's income as compared with what it would have been had all earnings been paid out as dividends. ${ }^{14}$

Even proponents of the Massachusetts rule agree that the Pennsylvania rule's goal of increasing income by obviating the effect of corporate reinvestment of earnings is commendable. ${ }^{15}$ However, apportionment under the Pennsylvania rule is complicated. Even when the trustee simply sells a share at a price higher than the purchase price, he must analyze the corporation's books for both the dates of purchase and sale to determine what part of the increase is attributable to retained earnings. Despite the best efforts of the Pennsylvania courts to

9 Earp's Appeal, 28 Pa. 368 (1857).

10 Bogert, Trusts \& Trusters $\S 842$ (2d ed. 1962) (hereinafter cited as BogerT); 3 ScotT $\S 286.8$.

11 In re Smith's Estate, 140 Pa. 344, 21 Atl. 438 (1891); Earp's Appeal, 28 Pa. 368 (1857). For descriptions of the Pennsylvania rule see Bogert \$§ 823, 841-48; Brigham, Pennsylvania Rules Governing the Allocation of Receipts Derived by Trustees From Shares of Stock, 85 U. PA. L. REv. 358 (1937); Cohan \& Dean, Legal, Tax and Accounting Aspects of Fiduciary Apportionment of Stock Proceeds: The Non-Statutory Pennsylvania Rules, 106 U. PA. L. REv. 157 (1957).

12 In re Nirdlinger's Estate, 290 Pa. 457, 139 Atl. 200 (1927). However, many states that purported to follow the Pennsylvania rule in other particulars did not apportion receipts from a sale of stock. See, e.g., In re Truang's Estate, 30 Cal. $2 \mathrm{~d} 811,185$ P.2d 201 (1947). Other apportionable events are the receipt of shares through a stock dividend, Earp's Appeal, 28 Pa. 368 (1857), or receipt of an extraordinary dividend, In re Leuder's Estate, 337 Pa. 155, 10 A.2d 415 (1940). See Cohan \& Dean, supra note 11.

13 Change in value is presumed to be change in book value. See In re Catherwood's Trust, 405 Pa. 61, 173 A.2d 86 (1961). But see In re Arrott's Estate, 383 Pa. 228, 118 A.2d 187 (1955).

14 See In re Jones' Estate, 377 Pa. 473, 105 A.2d 353 (1954); Earp's Appeal, 28 Pa. 368 (1857); BOCERT \& 842.

15 See, e.g., Minot v. Paine, 99 Mass. 101, 107 (1868) (conceding that the Massachusetts rule may injure the life tenant); BogerT $\$ \S 823,842$, 859; HOGG, RESEARCH IN TRUSTS AND THE TAXATION OF TRUST, 1931-60 at 37-48 (1963); 3 Scotr \$ 236.3; Brigham, supra note 11; Cohan \& Dean, supra note 11, at 158 n.7; Damrau, Apportionment of Stock Dividends in Trusts Created Prior to 1945, 15 U. PITr. L. REv. 34 (1953); Faught, Statutory Solution of the Problem of Allocation Between Life Tenant and Remainderman, 11 TEMP. L.Q. 139 (1937); Staver, Uniform Principal and Income Act, 21 ORE. L. REv. 217 (1942). The usual statement is that the Pennsylvania rule is "fairer" than the Massachusetts rule. See Hocg, supra, at $42-44$. 
simplify apportionment, the increasing complexity of corporate distributions has rendered the rule unworkable. ${ }^{18}$

The relative simplicity of the competing Massachusetts rule is achieved by refusing to divide between life tenant and remainderman any one type of receipt from stock: each receipt is allocated entirely to income or principal depending upon its form. As developed in the Uniform and Revised Uniform Principal and Income Acts, receipts from a sale of shares, ${ }^{17}$ shares received through stock dividends and splits, ${ }^{18}$ and "rights"19 are allocated to principal. Ordinary and extraordinary dividends in cash and in property other than shares of the distributing corporation, ${ }^{20}$ with the exception of payments in partial or total liquidation, ${ }^{21}$ are distributed as income. The simplicity of the Massachusetts rule led to its adoption in 1931 by the National Conference of Commissioners on Uniform State Laws. ${ }^{22}$ Subsequently, this example was followed by the American Law Institute, ${ }^{23}$ a majority of states, ${ }^{24}$ and even Pennsylvania. ${ }^{25}$

Although relatively simple to administer, the Massachusetts rule has several drawbacks. The primary problem results from the fact that corporations tend to reinvest about half of their earnings. ${ }^{26}$ By allocating only cash dividends to income, the Massachusetts rule allows corporate financial decisions to force the life tenant to accept a level of income lower than is necessary to maintain principal at a constant level. Thus, contrary to the postulated settlor's intent, the rule causes the value of a trust's stock holdings to rise over the long term, benefiting

16 See In re Catherwood's Trust, $405 \mathrm{~Pa} .61$, 173 A.2d 86 (1961).

17 UPI § 3(2); RPI § 3(b)(1); In re Martin's Trust Estate, 21 Wis. 2d 334, 346, 124 N.W.2d 297, 304 (1963).

18 UPI § 5(1); RPI § 6(a); Pentland v. Pentland, 113 So. $2 d 872$ (Fla. Ct. App. 1959); In re Estate of Valiquette, 122 Vt. 350, 173 A.2d 832 (1961). Stock dividends may be allocated to income under special circumstances involving reorganizations and dividend arrearages enumerated in $\S 6(b)$ of the RPI.

19 UPI § 5(2); RPI § 6(a). However, rights to subscribe to the shares of other corporations are designated as income under both the UPI and RPI. UPI $\S 5(2) ;$ RPI $\S 6(d)$.

20 UPI § 5(1); RPI § 6(d); see Minot v. Paine, 99 Mass. 101 (1868).

21 UPI § 5(3); RPI § 6(b)(3); see Wehrhane v. Peyton, 133 Conn. 478, 52 A.2d 711 (1947). For the distinction between extraordinary dividends and liquidation payments, see cases cited note 32 infra.

22 Commissioner's Prefatory Note, UPI, 9B UnIform Laws ANN. 366 (1957).

23 Restatement, Trusts $\S 236$ (Supp. 1948).

24 See note 2 supra.

25 PA. StAT. ANN. tit. 20, $\$ 3470.5$ (1964); see In re Catherwood's Trust, 405 Pa. 61, 173 A.2d 86 (1961).

26 Corporations paid out an average of $58 \%$ of their earnings from 1929 to 1960 , and an even lower percentage in the decade from 1950 to 1960. 1961 EconOMIc REPORT OF THE President 192 (1961). 
the remainderman instead of increasing current income and the value of the life interest. ${ }^{27}$

The Massachusetts rule also makes it more difficult to apply the prudent man rule of investment. This problem stems from the fact that different stocks, although equally prudent investments, may give their return in different forms. If the form of the return is allowed to govern the determination of the life tenant's income, investments of equal total return will produce significantly different income to the life tenant, and the trustee will have to consider this effect in making his investment decisions. For example, a trustee might decide to invest in growth stocks with the thought that their generally lower cash dividend payments ${ }^{28}$ will be offset by larger than average price increases and tax savings. However, the trustee who follows this prudent course would reduce the life tenant's income under the Massachusetts rule, which allocates only cash dividends to income. In order to fulfill his duty to act impartially, ${ }^{29}$ the trustee is compelled to balance his portfolio with bonds or high dividend yield stocks ${ }^{30}$ even if he thinks that these are less prudent investments because they offer lower total return. Thus, the need to consider the form of the return on stock investments appears to obstruct a prudent investment policy. ${ }^{31}$

27 It has been suggested that the remainderman should receive all gains because he bears the risk of loss. See In re Martin's Estate, 138 Misc. 216, 245 N.Y. Supp. 201 (Surr. Ct. 1930). However, this argument is weakened by the fact that, orer the long run, the likelihood of gain is greater than the risk of loss; therefore, giving the remainderman all gains overcompensates him for his risk of loss.

28 For example, in March 1966, IBM, General Electric, General Foods, Alcoa, Owens Illinois and Sears Roebuck all were yielding less than $3 \%$ on their common stocks; Xerox paid out $.31 \%$. At the same time, the stocks in Barron's fifty stock index were paying dividends at an annual rate of 3.62\%. Barron's Nat'l Bus. \& Financial Weekly, March 7, 1966, pp. $39 \cdot 45,58$.

Federal income tax considerations also favor investment in growth stocks. The payment of tax is postponed by paying a tax when the capital gain is realized, at the time the stock is sold, instead of paying a tax currently on dividends received. In addition, the tax rate on the return from capital appreciation is lower than it is on dividend income.

29 See In re Bissinger's Estate, 212 Cal. App. 2d 831, 28 Cal. Rptr. 217 (1963); Security Trust Co. v. Mahoney, 307 Ky. 661, 212 S.W.2d 115 (1948); Redfield v. Critchley, 227 N.Y. 336, I4 N.E.2d 377 (1998); BOGERT $§ 812,802$; 3 ScoTr $§ \S 232,240$; cf. In re Estate of Sheridan, 32 Misc. 2d 38, 222 N.Y.S.2d 751 (Surr. Ct. 1961).

30 See Duncan, Trustee Dilemma-What To Do About Growth Stocks, 100 Trusts \&. Estates 533 (1961). Clearly, the trustee must diversify his holdings, see, e.g., Pennsylvania Co. v. Gillmore, 142 N.J. Eq. 27, 59 A.2d 24 (1948), but ideally diversification should be based on economic considerations, not on the form in which the investment's profitability will be realized.

31 See Lovell, The Unitrust-A New Concept, Trust BuLL., Feb. 1966, pp. 21, 23-27. One former trust officer has said: "[T] rusts generally today are not securing all the benefits for life tenants and remaindermen that could be secured if instruments contained proper provisions to allow trustees to purchase low yielding investments or even invest- 
Problems of deciding whether particular receipts should be allocated to principal or income are also inherent in the Massachusetts rule's reliance on form. Thus, a trustee must decide whether a receipt is a liquidation payment allocable to principal or an "extraordinary dividend" allocable to income..$^{32}$ It is also likely that new forms of distribution will develop which are not clearly covered by the provisions of the rule, as occurred during the twenty-one years between the drafting of the original Uniform Act and the Revised Act. ${ }^{33}$

The defects of the Massachusetts rule have engendered a number of proposed modifications. For example, several states have adopted the rule that stock dividends be allocated to income instead of principal. ${ }^{34}$ The practical problem of distinguishing between a stock dividend and a stock split ${ }^{35}$ is avoided by defining a dividend as any distribution of the shares of a corporation which constitutes less than a specified percentage $^{36}$ of the outstanding shares of the same class. ${ }^{37}$

ments that have no present yield but which through plow-back of a large part of income might show substantial increases in value." Clark, Power To Invest Without Yield, 100 Trusts \& Estates 495 (1961). See, to the same effect, Duncan, supra note 30; Wells, Pity the Poor Income Beneficiary-How to Reconcile Growth and Yield?, 103 Trusts \& ESTATES 119 (1964).

32 See Wehrhane v. Peyton, 133 Conn. 478, 52 A.2d 711 (1947); Citizens \& So. Nat'l Bank v. Fleming, 181 Ga. 116́, 181 S.E. 768 (1935); Gifford v. Thompson, 115 Mass. 478 (1892); Jackson v. Jackson, 22 N.J. Super. 269, 91 A.2d 892 (Super. Ct. 1952); In re Bingham's Will, 7 N.Y.2d 1, 163 N.E.2d 301 (1959).

33 The Prefatory Note to the RPI states that one of the major reasons for revising the original act was the development of new forms of distribution. Commissioner's Prefatory Note, RPI, 9B UNIForm LAws ANN. (Supp. 1965). An example is duPont's court-ordered divestiture of General Motors stock, described in Barclay, Allocation of General Motors Stock on duPont Distribution, 101 Trusts \& Estates 140 (1962). The RPI § 6(b)(3), allocates court-ordered divestitures to principal, but this allocation question appeared so difficult under the UPI that one irustee testified at the duPont trial that trustees would be best advised to sell the stock immediately to avoid the problem. Dunham, $A$ Trustee's Dilemma as to Principal and Income, $26 \mathrm{U}$. CHI. L. Rev. $405 \mathrm{n} .2$ (1959).

Similarly, RPI \& 6(c) allocates capital gain dividends from mutual funds to principal, settling this point. Compare, e.g., Rosenburg v. Lombardi, 222 Md. 346, 160 A.2d 601 (1960), with Tait v. Peck, 346 Mass. 521, 194 N.E.2d 707 (1964).

34 See, e.g., PA. Stat. ANN. tit. 20, § 3470.5(1) (1964); N.J. Stat. Ann. 3A:I4A-4(a) (Supp. 1965); N.Y. Pers. Prop. LAW $\& 27-2(2)$.

35 The difficulty of deciding whether a particular stock distribution is a split or a dividend also occurs in cases where a settlor has provided that stock dividends are to be paid to the life tenant without defining a stock dividend. See, e.g., In re Bingham's Will, 7 N.Y.2d 1, 163 N.E.2d 301 (1961); Estate of Carlson, 16 App. Div. 2d 28, 224 N.X.S.2d 985 (1962); In re Pew, 398 Pa. 523, 158 A.2d 552 (1960).

36 New York and Pennsylvania use $6 \%$ as the dividing line, while New Jersey uses $4 \%$. See statutes cited note 34 supra.

37 In New York, for example, if five new shares were distributed for each one hundred shares outstanding, all five would be deemed income; a distribution of seven shares would be allocated entirely to principal. Paying out stock dividends to the life tenant gradually reduces the tax basis of the principal, since the trust's basis is divided among 
The advantage of assigning stock dividends to income is that the trustee, without lowering the life tenant's income, can invest in those companies which reinvest an abnormally high percentage of earnings but pay stock dividends. One recent study indicates that under the stock dividend rule the life tenant receives an average of $85 \%$ of the earnings of those companies which distribute stock dividends compared to $50 \%$ of the earnings of companies which pay only a normal cash dividend. ${ }^{38}$ However, it is clear that even under the stock dividend rule the trustee must still consider the form in which the investment will yield a return. Many corporations do not issue stock dividends despite abnormally high reinvestment. Even those that issue them do so at different rates; and the distributions of those corporations which declare only large, infrequent stock dividends are deemed stock splits and are allocated to the remaindermen. ${ }^{39}$

Two other allocation rules, the "constant percentage" and "annuity" methods, ${ }^{40}$ avoid the low income of the Massachusetts rule as well as its practical investment restrictions by abandoning form of return as the criterion for identifying the life tenant's income. The constant percentage rule allocates all receipts to principal, and on each payment date distributes as income a fixed percentage of the value of the principal.11 The annuity rule pays out a fixed dollar amount corrected for changes in purchasing power. Both of these approaches have significant advantages over the Massachusetts rule. They permit investment decisions to be made without regard to the form of return on the investment. If the rate is correctly determined, income is paid at the highest level consistent with maintenance of principal over the long term. Furthermore, both rules are easy to administer since they do not require classifying any particular receipt as income or principal.

The defect of these solutions is that the rate at which income is paid out must be determined in advance, making it difficult to insure that

individual shares, INT. REv. CODE of $1954, \S 307(a)$, and when the life tenant receives one of the shares he is not taxed on the amount of basis allocable to the share, INT. REv. CODE of 1954, § 1001(a). This reduction in basis reduces the after tax value of the gift to the remainderman when he receives the principal on termination. See INT. REV. CODE OF 1954, §§ 102(a), 1001(a); Note, Common Stocks in Trust, 113 U. PA. L. REv. 228, 256 n.129 (1964).

38 Shapleigh, The Six Percent Rule, 104 Trusts \& Estates 908 (1965).

39 See ibid.

40 Both methods are suggested in Carpenter, The "Fixed-Income," "Annuity" and "Modernized" Types of Trust, 5 LAw \& Contemp. Prob. 368 (1938). See Bocert § 813.

41 Such a rule applies only to stocks with an established market value; these would include stocks listed on an exchange or traded over the counter. It appears that most of the stocks held by trusts are listed and therefore have an established price. See Equity Changes in Trust Funds, 104 Trusts \& EsTATEs 1184 (1965). 
principal will not be systematically increased or depleted over the potentially long life of the trust, since the predicted rate of return may not correspond to the actual rate of return. This is especially difficult for an annuity trust, as a sharp drop in the market would cause the fixed payments to deplete principal. On the other hand, the constant percentage rule causes more fluctuation in income payments than does the Massachusetts approach, since the value of principal, reflecting stock prices, is characteristically more volatile than dividend payments. ${ }^{2}$

A recent law review comment suggests that the current rate of return on high grade bonds be used to determine income instead of a fixed percentage. ${ }^{43}$ This retains the advantage of eliminating the form of return as a factor in investment policy and avoids the difficulty of predicting in advance the percentage to be used to determine income. If, as in the present market, the bond rate is higher than the rate of cash return on stocks, ${ }^{44}$ this rule will also pay out more income than the Massachusetts rule. However, except for the years 1928-1930, 1933, and 1959 to the present, the bond rate has been lower than the rate of cash return on stocks. ${ }^{4 \overline{5}}$ Thus, unless it is desired to pay less income than does the Massachusetts rule, this proposal must be modified to allow the Massachusetts rule to operate when the bond rate is below the rate of cash return on stocks. This in turn means that the trustee will usually be faced with the defects of the Massachusetts rule, unless it is assumed that the present market will continue indefinitely. Also, a bond rate trust will produce greater variations in income than a comparable trust which consistently follows the Massachusetts rule: the life tenant will receive more in periods when the bond rate is in operation and less when the Massachusetts rule is in operation than he would under the strict Massachusetts rule. Principal must be paid out when the bond rate is higher than the rate of cash return on stocks; therefore, during the periods when the bond rate trust returns to the Massachusetts rule, it will have less principal, and consequently less income, than the strict Massachusetts rule trust, assuming equal performance.

42 As an extreme example, stock prices by 1932 had dropped by two-thirds of their 1929 level, while dividend payments dropped by less than half. In the more typical situation where stock prices drop sharply for a time and then recover, the constant percentage system would cause a correspondingly sharp decrease in payments to the life tenant while a system relying on cash dividends would maintain stable payments.

43 Note, Common Stocks in Trust, 113 U. PA. L. REv. 228 (1964).

44 In March 1966, bonds were yielding $4.89 \%$, while the dividend yield of Barron's fifty stock index was 3.62\%. Barron's Nat'l Bus. \& Financial Weekly, March 7, 1966, p. 58.

45 See Bureau of the Census, U.S. Dep't of Commerce, Historical Statistics of the United States 656 (1961); Bureau of the Census, U.S. Dep't of Commerce, Statisticat ABStRact OF THE UNited States 474 (1965). 
Also, it is not clear that the bond rate will necessarily produce constant principal values over the long term, even if it is used only in periods when the bond rate is higher than cash return on stocks. The bond rate will provide somewhat more income during a bull market than will the strict Massachusetts rule, but there is no apparent reason to assume that the resulting principal values and income payments will stay near a constant level as desired.

Another solution to both the investment restriction and the unnecessarily low income of the Massachusetts rule is to give the trustee discretion to allocate receipts as a prudent man would.46 This solution has much to recommend it: all definitional problems are avoided, and the trustee, by judicious allocation, can free himself both to invest rationally and to pay out as much to the life tenant as is consistent with preserving the ability of the corpus to earn income. ${ }^{47}$ In addition, the discretionary solution can be applied even to stocks which do not have an established market value, as would be impossible with the constant percentage rule. However, as useful as discretion may be in other contexts, ${ }^{48}$ it is deficient as a general solution to principal and income questions because it does not attempt to provide the "clear and uniform standard" which trustees need to guide their allocation decisions even when an individual settlor has committed the question to their discretion. ${ }^{49}$ Further, if a trustee's allocation produces results differing substantially from the widely accepted Massachusetts rule, as seems desirable, it may be attacked by the beneficiaries as "imprudent." 50 An allocation rule affording clear guidelines seems preferable. ${ }^{51}$

46 One state, Delaware, has adopted a discretionary rule as a general standard. DEL. CoDE ANN. tit. 12, § 3526(a) (Supp. 1964). Many trust instruments give discretionary power over allocation to individual trustees. See BocERT $\$ \$ 560-61,816$.

47 It appears, however, that trustees usually adhere strictly to the Massachusetts rule even when they have been granted discretion in allocation. See Subcommittee of Committee on 'Trust Administration and Accountability of Trustees, Trustees' Absolute and Uncontrolled Discretionary Powers, in American Bar Association, Section of Real Property Probate and Trust Law, Proceenings, Part I, 185, 192 (1965).

48 Discretionary power to invade principal to meet an unexpected need of a beneficiary is desirable. See Sanders, An Examiner's Views on Estate Planning, 99 Trusts \& Estates 485 (1960). To effect tax savings, the trustee can be authorized to distribute income among low tax bracket members of a class of beneficiaries. See Halbach, Problems of Discretion in Discretionary Trusts, 61 CoLUM. L. REv. 1425, 1453-55 (1961).

49 Commissioner's Prefatory Note, UPI, 9B Uniform Laws ANN. 365, 366 (1957).

50 Beneficiaries frequently charge that a trustee has abused his discretion in allocating a particular receipt. See, e.g., In re Heard's Estate, 107 Cal. App. 2d 225, 236 P.2d 810 (1951); Burden v. Colorado Nat'l Bank, 116 Colo. 111, 179 P.2d 267 (1947); Dumaine v. Dumaine, 301 Mass. 214, 16 N.E.2d 625 (1938); In re Watland, 211 Minn. 84, 300 N.W. 195 (1941); In re Clarenbach's Will, 23 Wis. 2d 71, 126 N.W.2d 614 (1964). See also BogerT $\S \S 560,561,816$; Halbach, supra note 48 , at 1428-33.

61 Trustees vigorously opposed the suggestion by Professor Dunham, the draftsman of 
An allocation rule which determines income independently of the form of return on stock investments seems to offer the most promising approach to avoiding the investment restrictions and unnecessarily low income to the life tenant which result from the Massachusetts rule. However, if a constant percentage is used, income fluctuates more than it does under a system which takes advantage of the relative stability of dividend payments, and the probability that the principal values and payments to the life tenant will rise or fall over the long run is increased under both the constant percentage and annuity rules because of the uncertainty involved in predicting investment performance in advance. These disadvantages can be reduced if, instead of a constant percentage, the current average rate of cash return on stocks held in all trusts is used as the income-determining percentage. ${ }^{.2}$ Although the use of either a constant percentage or a current average rate of cash return frees investment decisions from the necessity of considering the form of the prospective return, only the use of the current rate of return removes the necessity of predicting market performance in advance. Moreover, income to the life tenant does not fluctuate as much as it would if a constant percentage is used to determine this income, since the use of the current rate of cash return as the income determining percentage ties the life tenant's income to the rate of dividend payments, rather than to the more volatile stock prices. Thus, if the market falls suddenly, the rate of cash return will rise, assuming that dividends remain constant, and the life tenant's income will be correspondingly stable: if a constant percentage were used, the life tenant's income would fluctuate with the market value of the trust's stocks.

However, if income is paid at a rate which represents only cash dividends, principal will rise over the long term, reflecting the corporate policy of reinvesting half of earnings and the sustained growth of the economy. Therefore, a small percentage of principal in addition to that representing cash dividends should be paid as income to the life tenant, so that income is paid out at the highest rate consistent with maintenance of principal. This percentage should not be based on current price increases, since the increase in any one year may be lost in a later decline, and a policy of paying out every price increase would lead to ultimate depletion of principal since the cyclical losses would never be recouped. The percentage used to determine the life tenant's income

the RPI, that the discretionary rule be adopted. See the panel discussion reprinted in Uniform Revised Principal and Income Act, 101 TRUsts \& EsTATES 894, 896 (1962).

52 The individual trust's current rate of cash return cannot be used as the percentage, since investments of different cash yield would affect the life tenant's income, precisely the result this proposal attempts to avoid. 
representing price rises should therefore be a long term average of stock price rises, predicted from past market experience. This long term rise in prices has been about $3.35 \%$ per year, ${ }^{53}$ but because inflation has accounted for about one-third of this rise, the $3.35 \%$ figure should be reduced to $2 \% .^{54}$ This proposal contemplates that all receipts from common stocks be included in the trust corpus and that just prior to each payment date income will be determined by multiplying the current rate of cash return from stocks held in trust plus $2 \%$ by the current market value of the corpus.

The major difficulty with this proposed alternative to the Massachusetts rule is the possibility that the individual trust will consistently earn less than the average trust, thereby depleting principal. ${ }^{55}$ However, some deviation seems acceptable. The principal of a trust which pays out income at a rate higher than it actually earns on stock investments will decrease, but by maintaining the life tenant's income at a higher level, this rule has the beneficial effect of partially insulating the favored life tenant from the trustee's bad investment judgments. Eventually principal will decrease to the point that income is seriously impaired, but this will not occur at an alarming rate: a trust which consistently earned only $3 \%$ while the average yield of all trusts was $4 \%$ would lose only $10 \%$ of its original value in ten years, and only $25 \%$ of its value in thirty years. Of course, principal would be depleted more quickly if the rate of return actually earned is lower than this, 'but the possibility that the beneficiaries would be able to surcharge

53 This figure represents the average rate of price appreciation between 1926 and $1954-$ 1955. This period was used because it contains both major depression and sustained growth and because both 1926 and 1954-1955 seem to mark the beginning of strong bull markets after a period of relative stability. It may, however, be argued that these are not comparable points in the economic cycle and that $3.35 \%$ is therefore not a strictly accurate figure. If it is assumed that a depression of $1929-1939$ proportions will not again occur, a somewhat higher figure should be used. See generally, Fisher \& Lorie, Rates of Return on Investments in Common Stocks, 37 J. Bus. 1, 7 (1964).

54 The annual rise of stock prices in constant dollars for the period 1926-1955 was 2.22\%, and was rounded to $2 \%$ to facilitate calculation. See BUREAU OF THE CENSUS, U.S. DEP'T OF Commerce, Historical Statistics of the United States 125 (1961); Bureau of the Census, U.S. Dep't of Commerce, Statistical Abstract of the United States 361 (1965),

55 The possibility that returns on investment will be above average is not as objectionable, since one of the settlor's postulated goals, payment of highest sustainable income, is achieved as nearly as is practicable, while the other major goal, preserving the source of income, is not threatened by higher than average returns. Furthermore, the possibility that the proposed rule would actually provide less income to the life tenant than the Massachusetts rule, which would occur if the trustee succeeded in finding stocks whose cash return was more than $2 \%$ higher than the average cash return for all stocks, seems remote enough to be ignored, although it could be provided for by directing that either cash dividends actually received by the trust or the amount derived by using the formula should be paid to the life tenant, whichever were greater. 
the trustee for his failure to invest wisely would correspondingly increase. ${ }^{56}$

Further, it seems that deviation will not be significant over the long run. Analysis of this point must first look to the method used to determine the "average" rate. Since the average cash return and increase in market value of all actual trust investments in stock is not readily available, ${ }^{57}$ it is proposed that the rates be derived from a popular stock index, such as Standard \& Poor's Composite Index of 500 common stocks. This is an acceptable alternative, since all stock indexes, whether they contain a few high quality stocks or all the stocks listed on the New York Stock Exchange, appear to move together over the long run, ${ }^{58}$ leading to the conclusion that any well diversified trust should have investment results which are not consistently above or below that of the "average." Undiversified trusts may achieve a different return over the long run, but even smaller trusts may achieve diversification by investing in a common trust fund ${ }^{59}$ or mutual fund shares.

The value of the life interest in a trust is considerably different under the proposed rule and the Massachusetts rule. For two trusts which began with a $\$ 100,000$ corpus in 1947 , terminated in 1964, and achieved the same investment performance as the stocks in Standard \& Poor's Composite Index, the value in 1947 of the life interest in the trust under the proposed rule is nearly $25 \%$ higher than the value of the life interest in the Massachusetts rule trust, using a discount rate of $5 \% .{ }^{60}$ Similarly, the discounted value of the life interest in a $\$ 100,000$ trust starting in 1926 and ending in 1960 would have been over $12 \%$ greater under the proposed rule than under the Massachu-

56 See, e.g., Campbell v. AIbers, 313 Ill. App. 152, 39 N.E.2d 672 (1942); Gillingham Estate, 353 Pa. 493, 46 A.2d 269 (1946); BOGERT § 612; 2 SCOTT § 181.

57 An index which would closely approximate this, however, could be constructed by utilizing the quarterly survey of stocks held in trust based on a sampling of over 900 trust departments published by Trusts and Estates. See Equity Changes in Trust Funds, supra note 41.

58 See Fisher, Some New Stock Market Indexes, 39 J. Bus. 191, 204-05 (1966).

59 Investment in common trust funds is permitted by statute in more than 45 states. 3 Scotr § 227.9 at n.26 (Supp. 1965). See Bogue, Common Trust Fund Legislation, 5 LAw \&. CONTEMP. PROB. 430 (1938); Silverberg, Growth and Performance of Common Trust Funds in 1964, 2 National Bankrng Rev. 363 (1965); Stephenson, Participating InvestmentsThe Common Trust Fund Device, 12 OHIo Sr. L.J. 522 (1951).

60 These figures were calculated by determining the income payments and principal values for each of the years the hypothetical trusts were in existence, based on the stock price and yield data in Bureau of the Census, U.S. Dep't of Commerce, Historicai Statistics of the United States (1961); BuREau of the Census, U.S. Dep't of Commerce, Statistical Abstract of tHe United States (1965). All figures were corrected to dollars with the same purchasing power as the year the trust began, using the consumer price indexes from the same sources. The individual year's income payments were then discounted at a rate of $5 \%$ to obtain the value of the life interest at the origin of the trust. 
setts rule, even though both trusts would have paid the same amount of money by the end of the period. This is because the proposed rule pays out more income early in the life of the trust, compensating for the increasing yearly payments made by the Massachusetts rule trusts as their principal grows.

The life tenant's income fluctuates somewhat more under the proposed rule than does his income from the Massachusetts rule trust, ${ }^{61}$ but this is minor since only that part of the income payments which represents long term price rise moves with stock prices.

One general objection to the proposed rule is that it would eliminate the trustee's ability under the Massachusetts rule to vary income according to the needs of the life tenant, by switching to investments with higher or lower cash return. ${ }^{62}$ If this is objectionable, flexibility might be retained under the proposed rule by giving the trustee power to deviate by one per cent from the current income-determining percentage if justified by the life tenant's need. This would actually be an improvement on the discretion available under the Massachusetts rule, where the life tenant's needs may interfere with the investment policy producing the highest total return.

The Massachusetts rule of allocation for stock receipts, although commendable for its relative simplicity of operation, interferes with trustee investment decisions and does not provide as much income to the life tenant as the settlor probably intended. Even greater simplicity can be achieved and the investment restriction avoided if the life tenant's income is determined as a percentage of principal value rather than by reference to the form of receipts from stock. If the percentage to be used is determined by adding the current average rate of cash return on common stock investments by trusts and a figure representing average long term price increase, principal values and income payments would be steady over the long run, as the average settlor probably intended. These results can be obtained by inserting a clause similar to the following in an individual trust instrument or in the Revised Principal and Income Act: ${ }^{63}$

61 Short term fluctuations in the life tenant's income could be damped by requiring the trustee to adjust the current year's $2 \%$ payment by half of the difference between $2 \%$ of the principal for the current year and the year before it.

62 This appears to be a common practice, judging from the considerable weight given to the needs of the hypothetical life tenants in an investment selection exercise conducted by the American Bankers Association in 1945. Investment Management Problems Studied in Six Typical Trusts, Trust Bull., Dec. 1945, pp. 3, 15-19.

63 This rule should govern the construction of all trust instruments unless the trust 
Income from all stocks traded on an exchange or over the counter shall be determined in the following manner:

(1) On the income determination date, the market value of the stock and all property received in respect of the stock since the last income determination date shall be multiplied by the income determining percentage.

(2) The income determining percentage shall be derived by adding $2 \%$ per annum to the annual rate of cash return, on the income determination date, on stocks in a generally accepted stock index.

(3) The income payment date shall be fixed at least 2 weeks in advance; the income determination date shall be one week before the income payment date. ${ }^{64}$

instrument directs otherwise, regardless of when created: it is inconvenient for a trustee to apply two different rules to the trusts he administers, and, while it may be argued that the settlor relied on the Massachusetts rule when he created his trust, he would probably desire that improved allocation rules designed for current conditions be applied. See In re Allis' Will, 6 Wis. 2d 1, 94 N.W.2d 226 (1959); In re Catherwood's Trust, 405 Pa. 61, 173 A.2d 86 (1961); RPI $\S 14$.

64 The first clause of $\S 3$ is designed to reduce the possibility that a beneficiary will charge that the trustee has favored a competing beneficiary by selecting a particular income determination date in light of the stock prices on that date. The second clause insures that there will be sufficient time between the income payment and determination dates to perform administrative details such as deriving the income determining percentage and drawing checks. 